\title{
THE EFFECT OF CHEMICAL AND NON-CHEMICAL WEED MANAGEMENT METHODS ON CHEMICAL AND BIOLOGICAL PROPERTIES OF SOIL IN POTATO CULTIVATION IN ARDABIL PROVINCE, IRAN
}

\author{
AZADBAKHT, A. ${ }^{1}$ - ALEBRAHIM, M. T. ${ }^{*}$ - MOHAMMADDUST CHAMANABAD, H. R. \\ - GHAVIDEL, A. ${ }^{2}-$ KARBALAEI KHIAVI, $\mathrm{H}^{3}$ \\ ${ }^{I}$ Department of Agronomy and Plant Breeding, Faculty of Agricultural Science, University of \\ MohagheghArdabili, Ardabil, Iran \\ (e-mail: afsharazadbakht@uma.ac.ir; phone:+989380027313) \\ (e-mail:hr_chamanabad@yahoo.com; phone:+989151082239) \\ ${ }^{2}$ Department of Soil Science and Engineering, Faculty of Agricultural Sciences and Natural \\ Resources, University of MohagheghArdabili, Ardabil, Iran \\ (e-mail: ghavidel@uma.ac.ir; phone:+98912608412) \\ ${ }^{3}$ Agriculture and Natural Resources Research Center of Ardabil Province, Ardabil, Iran \\ (e-mail: Hossein.karbalaei@yahoo.com; phone:+98 9123501493) \\ *Corresponding author \\ e-mail:m_ebrahim@uma.ac.ir; phone:+989123501493 \\ (Received $17^{\text {th }}$ Dec 2016; accepted $7^{\text {th }}$ Mar 2017)
}

\begin{abstract}
The present study explores the effect of weed management practices on the properties of soil, including microbial biomass carbon (MBC), soil organic carbon (SOC), basal respiration (BR), induced respiration (IR), and microbial quotient (MQ) in potato cultivation at two agricultural research stations of Alarogh and Samian in Ardabil Province, Iran. We carried out a randomized complete block design with three replications. The treatments were as follows: 1) Trifluralin herbicide (TR), 2) Metribuzin herbicide (ME), 3) cultivator practice (CU), 4)wheat straw mulch (WH), 5) canola straw mulch (CA), 6) black plastic mulch (BPL), 7) transparent plastic mulch (TPL), 8) weed infested (WI), and 9) weed free (WF). Soil sampling was conducted at three stages. The first stage included control index sampling (CIS). The treatments employed in this research caused significant differences in the rates of MBC, SOC, BR, IR, and MQ. The highest rate of MBC was observed in WH and CA at the second and the third soil sampling stages, respectively, compared with other experimental treatments. WH and CA increased the rate of MBC in the second and the third sampling stages in comparison with CIS. The highest SOC was observed in WH and CA at the second and the third soil sampling stages. The highest BR at the second sampling stage was related to $\mathrm{CA}, \mathrm{WH}$, and BPL; however, the lowest BR at the second soil sampling stage was related to TR. Furthermore, the highest BR rate at the third sampling stage belonged to WH, CA, and ME. Nevertheless, IR had the highest rate in WH and CA and the lowest rate in the CU at the second sampling stage. Hence, we found that applying plant straw mulch treatments to cover the soil surface for weed management, compared to other methods employed in the experiment, had more positive effects on the biological characteristics measured.
\end{abstract}

Keywords: microbial biomass carbon, soil organic carbon, basal respiration, induced respiration, herbicide, mulch

\section{Introduction}

Soil microorganisms can be considered as the major components of biological processes and nutrient cycling in soil. In response to the importance of understanding the role of microorganisms in storing energy and nutrients and releasing them into soil, great attention has recently been devoted to estimating the microbial biomass of soil 
(Kiikkila et al., 2014; Wei et al., 2015). As the role of soil microbial biomass in changing the soil organic matter has been definitely proved, soil microbial biomass is often employed in the circulation and mineralization of the organic precursors (Luo et al., 2015; Leite et al., 2010). Researchers apply the changes in microbial biomass carbon as an indicator of soil fertility and ecological conditions of the environment (Boerner et al., 2000).Such operations as tillage, fertilization, crop rotation, and application of various cover crop types, which affect the properties of soil, can influence soil microbial diversity, microbial dynamics, microbial biomass, and status of soil microorganisms (Kumar et al., 2014; Zhang et al., 2012). The tillage could affect nutrient cycling, soil organic matter, and microbial activity by changing the temperature and humidity conditions of soil. The above-mentioned changes depend on the type and intensity of tillage (Roldan et al., 2005). Moreover, utilizing plastic mulch in a variety of crop management methods could affect the chemical and biological properties of soil (Zhang et al., 2015). For instance, applying these coatings can lead to changes in the chemical structure, moistness, and temperature under layer of itself. The marked changes can be regarded as important factors affecting the population growth, microbial biomass, and microbial respiration (Zhang et al., 2015; Li et al., 2013). Microbial quotient is equal to the ratio of microbial biomass carbon to soil organic carbon. Microbial quotient could be considered as a sensitive index for the evaluation of soil quality (Shirzadeh et al., 2013; Hu et al., 2011). Therefore, the present study aims to evaluate the effect of various weed management methods such as crop straw mulch, plastic mulch, cultivator, and herbicides on the soil microbial activity and community.

\section{Materials and Methods}

\section{Study area}

The present experiment was conducted in 2015 at two stations: 1. Alarogh Agricultural Research Stationin Ardabil Province, Iran with an altitude of 1350 meters above sea level, a longitude of $48^{\circ}, 20^{\prime}$, a latitude of $38^{\circ}, 15^{\prime}$, a semi-arid and cold climate, and a soil pH of 7.6, and 2. Samian Agricultural Research Station in Ardabil Province, Iran with an altitude of 1320 meters above sea level, a longitude of $48^{\circ}, 15^{\prime}$, a latitude of $38^{\circ}, 23^{\prime}$, a semi-arid and cold climate, and a soil $\mathrm{pH}$ of 7.5-8. The laboratory measurements were performed at the Faculty of Agricultural Sciences and Natural Resources, University of Mohaghegh Ardabili, Ardabil, Iran.

\section{Experimental design and treatments}

The present study employed a randomized complete block design with three replications. The treatments were as follows: 1) Spraying Trifluralin herbicide (TR) on the soil between the rows of potato plants $(75 \% \mathrm{EC}$ was formulated with the amount of $2 \mathrm{~L} /$ ha by the Matabi model with an 8001 nozzle and the constant speed and pressure of sprayer in all treatments based on the $250 \mathrm{~L} / \mathrm{ha}$ spraying; thus, the Trifluralin was mixed with soil at the depth of $0-10 \mathrm{~cm}$ ) immediately after the second hilling of potato plants 45 days after planting the potatoes. 2) Spraying Metribuzin herbicide (ME) on the soil between the rows of potato plants with the amount of $1000 \mathrm{~g} / \mathrm{ha}$ (with the formulation of $70 \% \mathrm{WP}$ and sprayer specification such as the sprayer used for Trifluralin herbicides) immediately after the second soil hilling of potato plants 45 days after planting the potatoes. 3) Cultivator practice (CU) once for 20 days after the second hilling of potato 
plants 65 days after planting the potatoes. 4) Wheat straw mulch (WH) with the amount of $5 \mathrm{t} / \mathrm{ha}$ and thickness of $15 \mathrm{~cm}$ immediately after the second soil hilling of potato plants 45 days after planting the potatoes. 5) Canola straw mulch (CA) applied similar to that of WH treatment. 6) The application of black plastic mulch (BPL), covering the space between the rows with plastic sheets with the thickness of 50 microns immediately after the second soil hilling of potato plants 45 days after planting the potatoes in the plot or row. 7) The application of transparent plastic mulch (TPL) was similar to that of BPL treatment. 8) Weed infested (WI), no weed removal in the entire growing season. 9) Weed free (WF) or weed removal in the entire growing season in both stations.

\section{Land preparation}

The land was prepared for planting by secondary plowing and immediately after favorable weather and soil conditions. On $5^{\text {th }}$ June 2015, potato tubers (a variety of Agria) were hand-planted in rows, between which there was a distance of $75 \mathrm{~cm}$ and a distance of $25 \mathrm{~cm}$ on the ridge (the distance between the tubers planted on the planting row in each plot). Each plot had an area of $3 \times 3.5 \mathrm{~m}$.

\section{Soil sampling and sample preparation}

Soil sampling was carried out in three stages. The first sampling stage was the indexsampling (CIS) performed immediately before applying any treatments. The procedures in the first sampling stage were as follows: 5 samples were collected from each station (the samples were collected at the points of $\mathrm{W}$ from each station) and combined as one sample (combined data) to be compared with the samples collected from the following two sampling stages. The second sampling stage was conducted one month after applying the treatments (55 days after planting the potatoes). The third sampling stage was executed two months after applying the treatments (75 days after planting the potatoes). In the second and the third sampling stages, three soil samples were collected from a depth of $0-5 \mathrm{~cm}$ from different points of each plot (treatment) and subsequently mixed. All samples were collected, packaged in plastic bags, placed within the flasks containing ice, and transferred to laboratory. The samples were kept (a maximum of 7 days) in the thermal conditions of $4^{\circ} \mathrm{C}$ in darkness until the biological and chemical properties were measured. In order to determine the physical and chemical properties of soil, a portion of the soil collected was air-dried in the laboratory.

\section{Microbial biomass carbon (MBC)}

MBC was measured, using the fumigation-extraction method (Wu et al., 1990). In summary, the first wet soil sample, $20 \mathrm{~g}$ dried soil, was extracted from $40 \mathrm{~mL}$ of $0.5 \mathrm{M}$ (Molar) $\mathrm{K}_{2} \mathrm{SO}_{4}$, shaken for $30 \mathrm{~min}$, and refined in a vacuum extraction system by applying Whatman filter paper (No. 42). The second wet soil sample, 20-g dried soil, was fumigated by $\mathrm{K}_{2} \mathrm{SO}_{4}$ for $48 \mathrm{~h}$ rather than being extracted by $40 \mathrm{~mL}$ of $0.5 \mathrm{M} \mathrm{K}_{2} \mathrm{SO}_{4}$ which was employed in the previous soil sampling preparation. To determine the level of carbon dissolved, the samples extracted were kept frozen until the time of analysis. Extractable carbon was measured, using Shimadzu total soil organic carbon analyzer. Moreover, MBC was measured by considering the disparity of organic carbon values between the fumigated and control samples and was differentiated by a $\mathrm{K}_{\mathrm{ec}}$-factor of 0.45 (Yao et al., 2000). 


\section{Soil organic carbon (SOC)}

SOC was specified, using a dichromate or $\mathrm{K}_{2} \mathrm{CrO}_{4}$ oxidation and was then titrated by standard ferrous solution ( $\mathrm{Lu}, 2000)$.

\section{Basal respiration $(B R)$}

To perform and determine BR, a small dish containing $20 \mathrm{~mL}$ of 0.5 normal $\mathrm{NaOH}$ inside a plastic container with a capacity of one liter was placed in $20 \mathrm{~g}$ of moist soil (holding about $50 \%$ of the soil capacity). A fully insulated lid was used to prevent any exchanges of gas with the atmosphere. Afterwards, it was placed in the incubator for 24 $\mathrm{h}$ at the temperature of $28^{\circ} \mathrm{C}$. The contents of the beaker were transferred into a $250 \mathrm{~mL}$ Erlenmeyer flask containing $2 \mathrm{~mL}$ of $0.5 \mathrm{M}$ barium chloride and 3 to 4 drops of Phenolphthalein; following that, the contents were titrated, using 0.1 normal HCL. Basal respiration was measured according to the following equation expressed in $\mathrm{mg}$ $\mathrm{CO}_{2}$ per $100 \mathrm{~g}$ of soil per hour (Anderson, 1982). Basal respiration was calculated by unit of milligrams $\mathrm{CO}_{2} \times 100 \mathrm{gdm}^{-1} \mathrm{~h}^{-1}$ via the following formula:

$$
\frac{\left(\mathrm{V}_{1}-\mathrm{V}_{2}\right) \times \mathrm{N}_{\mathrm{HCL}} \times 22}{\mathrm{md}}
$$

The $V_{l}$ is volume of acid utilized in the control sample (milliliter), $V_{2}$ is the volume of acid consumed in soil samples, and $N$ is Hydrochloric acid, 22 equivalent grams of $\mathrm{CO}_{2}$.

\section{Induced respiration (IR)}

To perform and determine IR, $50 \mathrm{~g}$ of the each soil sample was weighed and taken into a $1 \mathrm{~L}$ plastic container. One $\mathrm{mL}$ of $1 \%$ glucose as the substrate was added to the each soil sample. Simultaneously, a small beaker containing $10 \mathrm{~mL}$ of normal $0.1 \mathrm{M}$ $\mathrm{NaOH}$ was placed inside the container, and then its lid was closed. The samples collected were placed in an incubator for 6 hours at $28^{\circ} \mathrm{C}$ in constant state. The contents of the beaker were then transferred to the Arlon container and titrated with 0.1 normal HCL. Induced respiration with added glucose rates was calculated based on the method introduced by Alef and Nannipieri (1995).

\section{Microbial quotient (MQ)}

MQ was obtained by the following formula:

$$
(\mathrm{MQ})=\frac{\text { Microbialbiomasscarbon }}{\text { Soil organic carbon }}
$$

In each of the sampling stages, the treatments were compared with each other. The analysis was performed by MSTATc software. Furthermore, the Excel software was employed to provide the charts. 


\section{Results and Discussion}

\section{Microbial biomass carbon (MBC)}

The results revealed that the treatments administered could lead to significant differences in the amount of MBC (Tables 1 and 2). The highest rate of MBC was observed in treatments in both of the second and the third sampling stages. WH and CA could increase MBC rate in the second sampling stage in comparison with the CIS stage. WH and CA increased the MBC rate by $29.30 \%$ and $21.39 \%$ in the second stage and $58.45 \%$ and $55.19 \%$ in the third stage, respectively, compared to CIS (Fig. 1). It appears that in comparison with plastic mulches, herbicide, and cultivator treatments, crop residues have provided more energy for the growth of microorganisms; in addition, they have increased the operation of the biological factor activity of soil due to increasing the organic precursors and carbon compounds such as sugars, amino acids, and organic acids (Alvear et al., 2005; Li et al., 2013).

Table 1. Combined statistical analysis (ANOVA) of the effects of experimental treatments on microbial biomass carbon, soil organic carbon, and microbial quotient in the second sampling stage

\begin{tabular}{|c|c|c|c|c|}
\hline \multirow[b]{2}{*}{ (S.O.V) } & \multirow[b]{2}{*}{ Df } & \multicolumn{3}{|c|}{ Mean of squares } \\
\hline & & $\begin{array}{l}\text { Microbial biomass } \\
\operatorname{carbon}\left(\mathrm{mgCgdm}^{-1}\right)\end{array}$ & $\begin{array}{c}\text { Soil } \\
\text { organic } \\
\text { carbon } \\
(\%)\end{array}$ & $\begin{array}{c}\text { Microbial } \\
\text { quotient(MQ) } \\
\left(\mathrm{mgC}_{\text {mic }} \mathbf{g}^{-1} \mathrm{C}_{\text {org }}\right)\end{array}$ \\
\hline Station & 1 & $7709.3^{\mathrm{ns}}$ & $9.2^{\mathrm{ns}}$ & $61856.04^{\mathrm{ns}}$ \\
\hline Rep (Station) & 4 & 14287.5 & 0.1 & 1294.7 \\
\hline Treatments & 8 & $108821.1^{* * *}$ & $0.2^{* *}$ & $3175.4^{*}$ \\
\hline Station $\times$ Treatment & 8 & $7546.3^{\mathrm{ns}}$ & $0.1^{\mathrm{ns}}$ & $2062.1^{\mathrm{ns}}$ \\
\hline Error & 32 & 9631.3 & 0.08 & 1022.05 \\
\hline $\mathrm{CV}$ & - & 9.03 & 21.03 & 32.45 \\
\hline
\end{tabular}

ns, non-significant difference. ${ }^{* *}$, difference in level 1 percent. ${ }^{*}$, difference in level 0.5 percent

Table 2. Combined statistical analysis (ANOVA) of the effects of experimental treatments on microbial biomass carbon, soil organic carbon, and microbial quotient in the third sampling stage

\begin{tabular}{|c|c|c|c|c|}
\hline \multirow[b]{2}{*}{ (S.O.V) } & \multirow[b]{2}{*}{ Df } & \multicolumn{3}{|c|}{ Mean of squares } \\
\hline & & $\begin{array}{l}\text { Microbial biomass } \\
\operatorname{carbon}\left(\mathrm{mgCgdm}^{-1}\right)\end{array}$ & $\begin{array}{c}\text { Soil } \\
\text { organic } \\
\text { carbon } \\
(\%)\end{array}$ & $\begin{array}{c}\text { Microbial } \\
\text { quotient(MQ) } \\
\left(\mathrm{mgC}_{\text {mic }} \mathbf{g}^{-1} \mathrm{C}_{\text {org }}\right)\end{array}$ \\
\hline Station & 1 & $753421.8^{\mathrm{ns}}$ & $8.5^{\mathrm{ns}}$ & $129779.4^{\mathrm{ns}}$ \\
\hline Rep (Station) & 4 & 168997.03 & 0.04 & 6756.5 \\
\hline Treatments & 8 & $587555.6^{* *}$ & $0.5^{* *}$ & $7821.8^{*}$ \\
\hline Station $\times$ Treatment & 8 & $138760.4^{\mathrm{ns}}$ & $0.05^{\mathrm{ns}}$ & $3854.2^{\mathrm{ns}}$ \\
\hline Error & 32 & 87327.5 & 0.1 & 2735.4 \\
\hline $\mathrm{CV}$ & - & 16.43 & 26.8 & 30.4 \\
\hline
\end{tabular}

ns, non-significant difference. **, difference in level 1 percent. ${ }^{*}$, difference in level 0.5 percent 


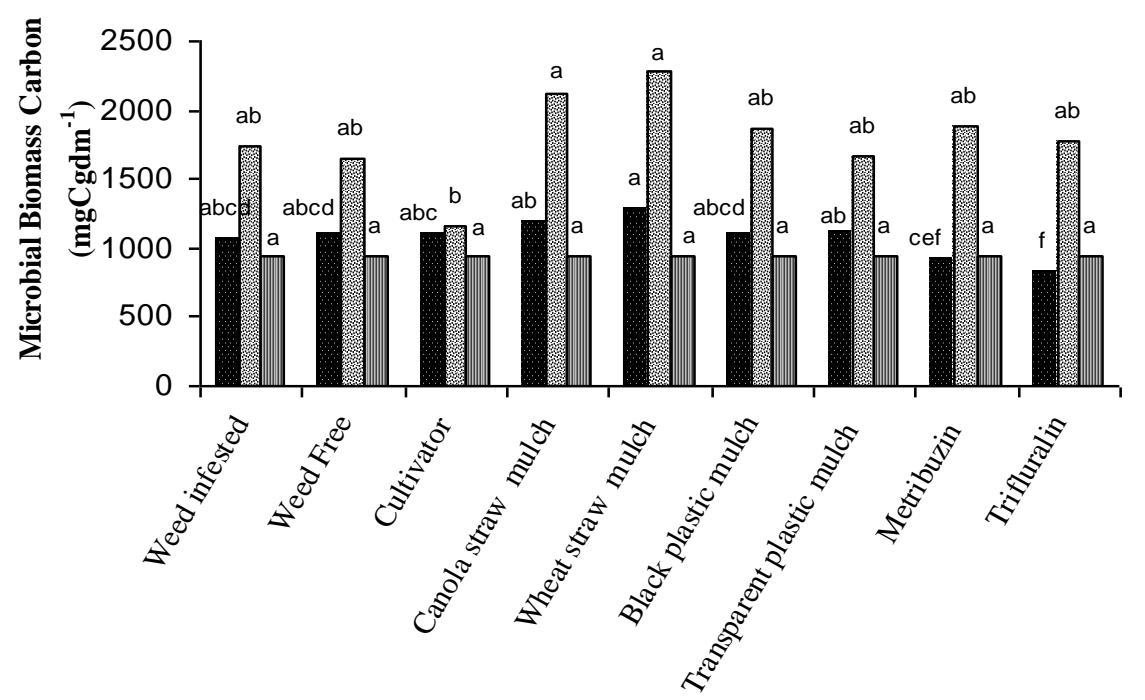

Weed management treatments

Figure 1.The effect of experimental treatments and stages (times) of sampling on microbial biomass carbon of soil in potato cultivation (Means in each column followed by at least one similar letter are not significantly different at 5\% probability level, using Duncan's multiple range test.)

The minimum rate of MBC was observed in the second sampling stage in TR and ME. The MBC rate significantly decreased in TR and ME in comparison with $\mathrm{WH}$ and $\mathrm{CA}$. Moreover, $\mathrm{MBC}$ rates in TR and ME in the second sampling stage were $13.86 \%$ and $1.57 \%$ which decreased in comparison with CIS (Fig. 1). In a research conducted by Shahrad (2010), the rates of microbial respiration, microbial population, and soil organic matter were measured in a spectrum of time after applying Trifluralin herbicide. The results indicated that the amount of $\mathrm{CO}_{2}$ production decreased with the passage of time, and this reduction continued until the fourth week; however, the amount of $\mathrm{CO}_{2}$ production was reported to increase in the fifth week.

The trend presented was also reported to be observable in the Rhizosphere and nonRhizosphere soil. The bacterial population rate was reduced over time due to the presence of herbicides. The above-mentioned trend was obvious by considering the amount of $\mathrm{CO}_{2}$ production. This negative trend lasted until the beginning of the decomposition of herbicides. This decomposition provided the soil with rich carbon and nitrogen sources and increased the bacterial population. Probably the increased production of $\mathrm{CO}_{2}$ in the fifth week could be associated with the increased bacterial growth. In experiments conducted by Song et al. (2013), it was found that utilizing Trifluralin herbicide in the potato crop had a minor effect on soil bacteria and fungi. The maximum activity of Metribuzin herbicides in soil is 30 days after applying them. Over this period, the activity and population of soil microorganisms decline. This process occurs due to the herbicides that inhibit the enzymatic and biological activity of the microorganisms, thus leading to an increase in the population and activity of soil microorganisms. 
Hence, it appears that in response to the degradation of herbicides by soil microorganisms, metabolites are produced which are later applied as food sources for soil microorganisms. This process leads to the growth in population and enhancement in respiration of soil microorganisms (Zaki et al., 2014). In the third sampling stage, the minimum rate of $\mathrm{MBC}$ was related to $\mathrm{CU}$, which could significantly reduce the MBC rate in comparison with WH and CA (Tables 1 and 2). Furthermore, the MBC rate presented a slight increase in CU treatment in the second and the third sampling stages; however, other treatments had shown a significant increase in the MBC rate (Fig. 1).

Microbial biomass and microbial processes are significantly higher in no-tilled soil compared to tilled soil (Helgason et al., 2010; Leite et al., 2010). Balota et al. (2004) specified that the reason for the increase in microbial activity in no-tillage condition is related to the improved microbial habitat formation and stability of large soil aggregates, thus supplying an important habitat for microbial activity and biomass.

\section{Soil organic carbon (SOC)}

The results of the present study indicated that the experimental treatments had a significant effect on the amount of SOC (Tables 1 and 2). The highest SOC rate was observed in $\mathrm{WH}$ and $\mathrm{CA}$ in comparison with other treatments during the second and the third sampling stages. WH could increase the SOC rate up to $31.92 \%$ and $29.81 \%$ in the second and the third sampling stages, respectively. The SOC rates obtained in the CA treatment were $36.51 \%$ and $31.05 \%$ in the second and the third sampling stages, respectively (Fig. 2). It appears that in comparison with other treatments, adding plant straw mulch to soil increases the amount of input carbon in the soil. Moreover, as organic matter constitutes approximately $50 \%$ of the soil mass, adding plant straw mulch to soil improves the chemical and biological properties of the soil, provides the conditions for decomposition of plant straw, improves microbial activity, and consequently increases the total organic carbon of soil (Certini, 2005; Li et al., 2013). However, the minimum rate of SOC in the second sampling stage was related to the TPL treatment with a rate of $1.06 \%$, being lower than the $6.6 \%$ rate of SOC in CIS. With respect to the third sampling stage, the minimum rate of SOC was related to TPL and BPL which presented lower SOC rates in comparison with that of CIS treatment.

However, it must be mentioned that these differences were not statistically significant (Fig. 2). In response to the growth and photosynthetic activity of plants, the present SOC in the atmosphere is converted into the organic compounds by the plant. These compounds are shifted from the leaves as the source to the roots; in addition, in the form of seeping, they are transferred into the soil of farm, where plastic mulch is employed to cover the soil surface by adding the residue. Furthermore, the waste of plants is prevented from seeping into the soil during the crop growing season; hence, the microbial demand for the carbon source quickly reduces in the soil as it is dependent on this carbon source. The above-mentioned process can be regarded as one of the factors reducing the amount of organic carbon in the soils covered with plastic mulches and plastic covers (Fontaine et al., 2007). 


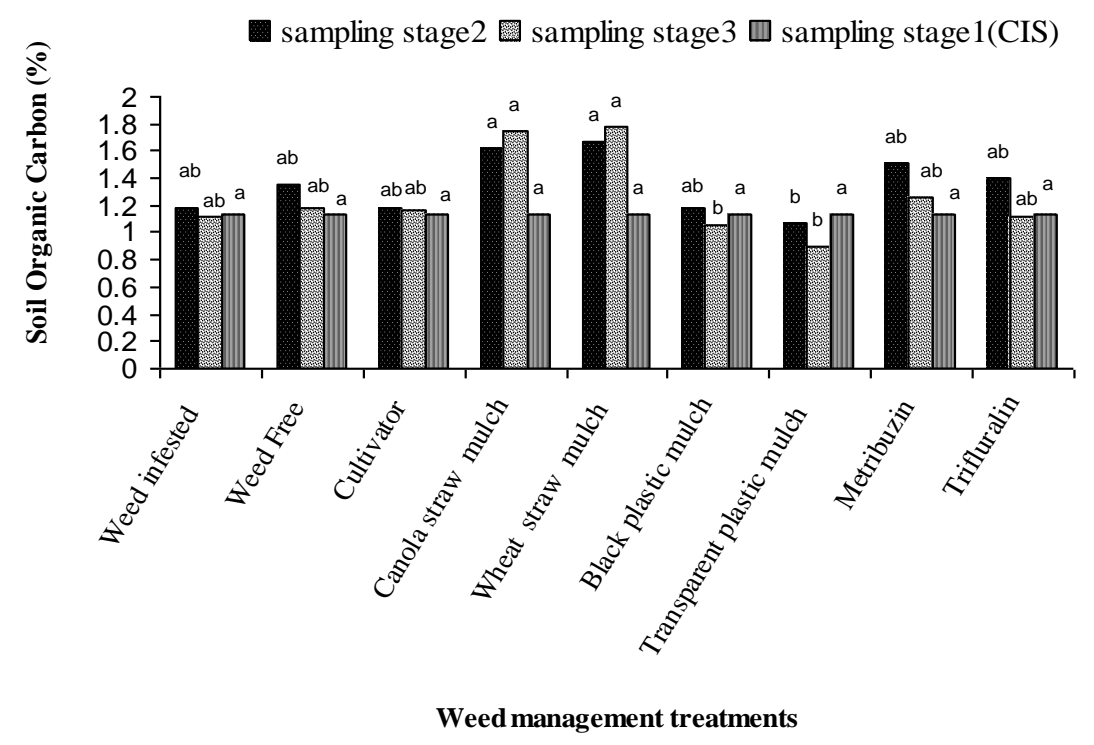

Figure 2. The effect of experimental treatments and stages (times) of sampling on soil organic carbon of soil in potato cultivation (Means in each column followed by at least one similar letter are not significantly different at 5\% probability level, using Duncan's multiple range test.)

\section{Basal respiration $(B R)$}

In the present study, the BR rate was significantly affected by the treatments in both of the second and the third sampling stages (Tables 3 and 4). The highest rate of BR in the second stage was related to $\mathrm{CA}, \mathrm{WH}$, and BPL treatments, resulting in the BR rates of $49.83 \%, 42.96 \%$ and $31.27 \%$, respectively. However, only was the BR rate in CA statistically different from those of CIS and TR (Table 2). Plant straw mulch utilized in the farming period could produce a significant effect on the variations of microbial biomass, microbial respiration, and microbial population by affecting the availability of sources, energy, and carbon resources as well as modifying the physical environment (Spehn et al., 2000). The minimum rate of BR during the second sampling stage belonged to TR, WF, and WI. However, only was the BR rate in the CA statistically different from those in TR, WF, and WI treatments. Nevertheless, only could the TR treatment, not the WF and WI treatments, demonstrate a significant difference in the BR rate in comparison with the other experimental treatments (Fig. 3). The significant reduction in the $\mathrm{BR}$ rate in $\mathrm{TR}$ can be attributed to the negative toxic impact of Trifluralin on the growth and other biological activities of the bacteria, fungi, and other microorganisms (Torabi et al., 2013).

There is a great number of such actions on enzymes and proteins in plants; for example, the Acetolactate synthase enzyme carries out the synthesis of amino acids, Valine, Leucine, and Isoleucine in weeds and Rhizobium (Xia et al., 2012; Torabi et al., 2013). During the third sampling stage, the highest rate of BR belonged to WH, CS, and ME treatments. It can be interpreted that possibly the addition of plant residues to the soil surface prevents high evaporation (the moistness of water) from the soil surface and leads to absorbing moisture by the organic matter of soil. Furthermore, a better soil environment is provided in terms of humidity, temperature, and nutrient requirements for microbial activity (Qiu et al., 2012; Li et al., 2013; Kiikkila et al., 2013). 


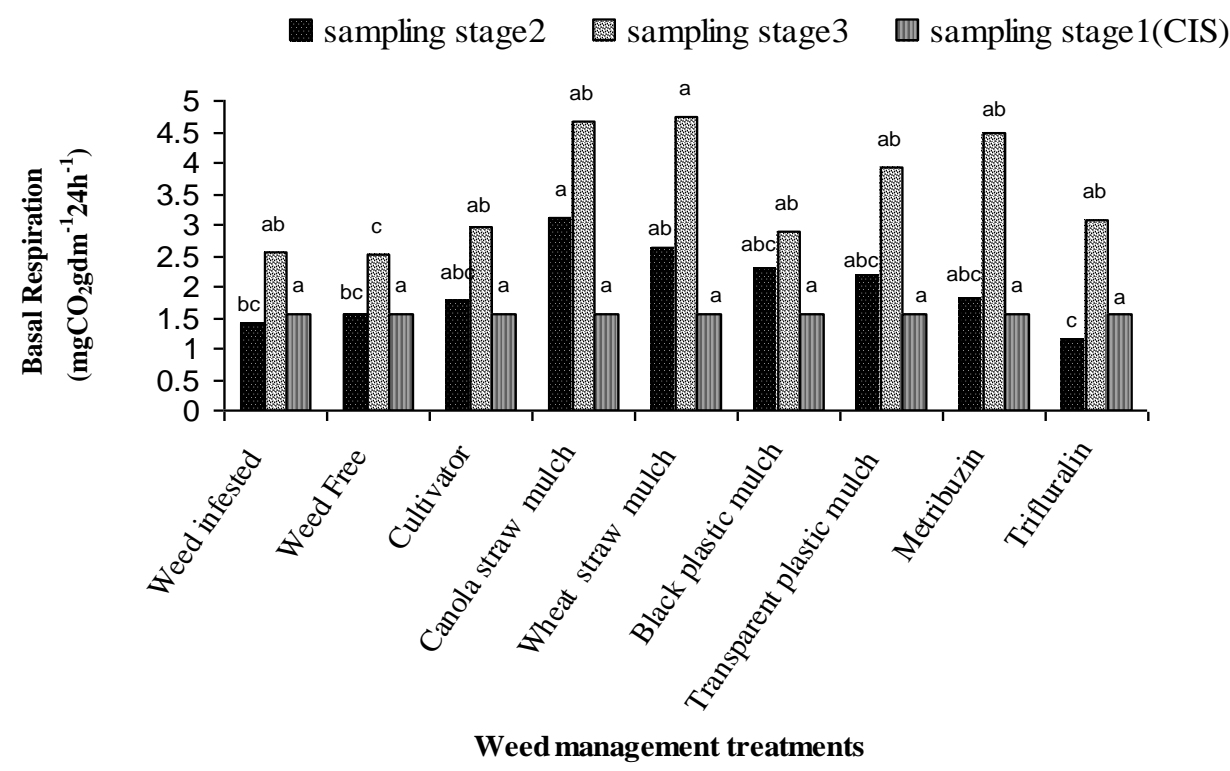

Figure 3.The effect of experimental treatments and stages (times) of sampling on basal respiration of soil in potato cultivation (Means in each column followed by at least one similar letter are not significantly different at 5\% probability level, using Duncan's multiple range test).

\section{Induced respiration (IR)}

Based on the results of variation analysis (Tables 3 and 4), the IR rates were considerably affected by the treatments employed in the second and the third sampling stages. In the second sampling stage, the highest IR rates were related to $\mathrm{WH}$ and $\mathrm{CA}$ with $57.48 \%$ and $44.08 \%$, respectively; these rates were more than that in the CIS although the $\mathrm{WH}$ and $\mathrm{CA}$ treatments did not show significantly different rates. The lowest IR rate in the second sampling stage was related to $\mathrm{CU}$ which presented a substantially different IR rate in comparison with CIS (Fig. 4).In the third sampling stage, the increase in the IR rate was larger than that of the second sampling stage.

Table 3. Combined statistical analysis (ANOVA) of the effects of experimental treatments on basal induced and stimulated respiration in the second sampling stage

\begin{tabular}{|c|c|c|c|}
\hline \multirow[b]{2}{*}{ (S.O.V) } & \multirow[b]{2}{*}{ Df } & \multicolumn{2}{|c|}{ Mean of squares } \\
\hline & & $\begin{array}{l}\text { Basal respiration } \\
\left(\mathrm{mgCO}_{2} \mathrm{gdm}^{-1} 24 \mathrm{~h}^{-1}\right)\end{array}$ & $\begin{array}{l}\text { Induced respiration } \\
\left(\mathrm{mgCO}_{2} .100 \operatorname{gdm}^{-1} h^{-1}\right)\end{array}$ \\
\hline Station & 1 & $0.1^{\mathrm{ns}}$ & $14.5^{\mathrm{ns}}$ \\
\hline Rep (Station) & 4 & 0.2 & 2.5 \\
\hline Treatments & 8 & $2.2^{* *}$ & $27.1^{*}$ \\
\hline Station $\times$ Treatment & 8 & $0.6^{\mathrm{ns}}$ & $30.1^{*}$ \\
\hline Error & 32 & 0.5 & 11.4 \\
\hline $\mathrm{CV}$ & - & 36.4 & 53.06 \\
\hline
\end{tabular}

ns, non-significant difference. $* *$, difference in level 1 percent. *, difference in level 0.5 percent 
Table 4. Combined statistical analysis (ANOVA) of the effects of experimental treatments on basal respiration and induced respiration in the third sampling stage

\begin{tabular}{|c|c|c|c|}
\hline \multirow[b]{2}{*}{ (S.O.V) } & \multirow[b]{2}{*}{ Df } & \multicolumn{2}{|c|}{ Mean of squares } \\
\hline & & $\begin{array}{c}\text { Basal respiration } \\
\left(\mathrm{mgCO}_{2} \mathrm{gdm}^{-1} 24 \mathrm{~h}^{-1}\right)\end{array}$ & $\begin{array}{l}\text { Induced respiration } \\
\left(\mathrm{mgCO}_{2} \cdot 100 \mathrm{gdm}^{-1} \mathrm{~h}^{-1}\right)\end{array}$ \\
\hline Station & 1 & $69.1^{\mathrm{ns}}$ & $0.7^{\mathrm{ns}}$ \\
\hline Rep (Station) & 4 & 2.1 & 11.08 \\
\hline Treatments & 8 & $5.09^{*}$ & $34.6^{* *}$ \\
\hline Station $\times$ Treatment & 8 & $3.6^{\mathrm{ns}}$ & $3.05^{\mathrm{ns}}$ \\
\hline Error & 32 & 1.7 & 6.3 \\
\hline $\mathrm{CV}$ & - & 37.6 & 35.9 \\
\hline
\end{tabular}

ns, non-significant difference. ${ }^{* *}$, difference in level 1 percent. ${ }^{*}$, difference in level 0.5 percent

sampling stage 2 sampling stage 3 血 sampling stage 1 (CIS)

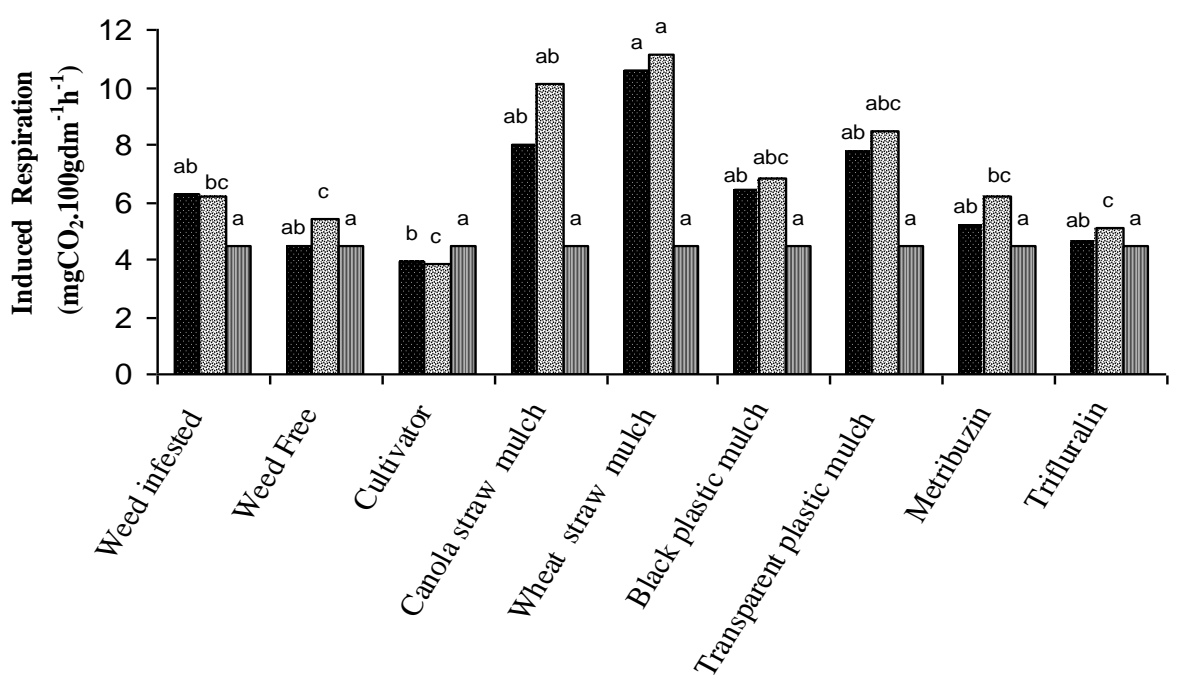

Weed management treatments

Figure 4.The effect of experimental treatments and stages (times) of sampling on induced respiration of soil in potato cultivation (Means in each column followed by at least one similar letter are not significantly different at 5\% probability level, using Duncan's multiple range test.)

In other words, the increase in the IR rate after two months was more remarkable in the third sampling stage, indicating that with the passage of time, the decomposition of plant mulches increased; moreover, further crop leakage was added to the soil, increasing the amount of organic material in the soil. Furthermore, herbicide decomposition, carbon source, or food source increased for soil microorganisms, thus increasing the population of microorganisms and soil respiration (Tejada et al., 2009; Vandana et al., 2012). Microbial biomass carbon grows as a result of utilizing organic manure because it provides an appropriate field or context for soil Microbiota, stimulating Microbiota activity and consequently leading to an increase in respiratory enzyme activity and soil microbes (Tejada et al., 2009; Hu et al., 2011; Zhang et al., 2012; Qiu et al., 2012). 


\section{Microbial quotient (MQ)}

Measurements of the MQ rate in the present study revealed that this parameter decreased in all treatments in the second stage compared with CIS (Tables 1 and 2). However, among all of the experimental treatments in the second sampling stage, the highest MQ rates were related to TPL and CU treatments, i.e.132.99 and $127.86 \mathrm{mg} \mathrm{C}$ micg $^{-1} \mathrm{C}$ org, which increased by $32.10 \%$ and $34.40 \%$, respectively, compared to CIS. In point of fact, TPL and CU had the minimum decrease in the MQ rate in comparison with CIS and all other treatments conducted in the second sampling stage (Fig. 5). In the third sampling stage, with the passage of two months, the trends of the MQ rate changed. TPL, WI, and TR treatments demonstrated the MQ rates of $25.31 \%, 11.83 \%$, and $4.08 \%$, respectively, presenting an increase in the MQ rate compared with the CIS stage (Fig. 5).

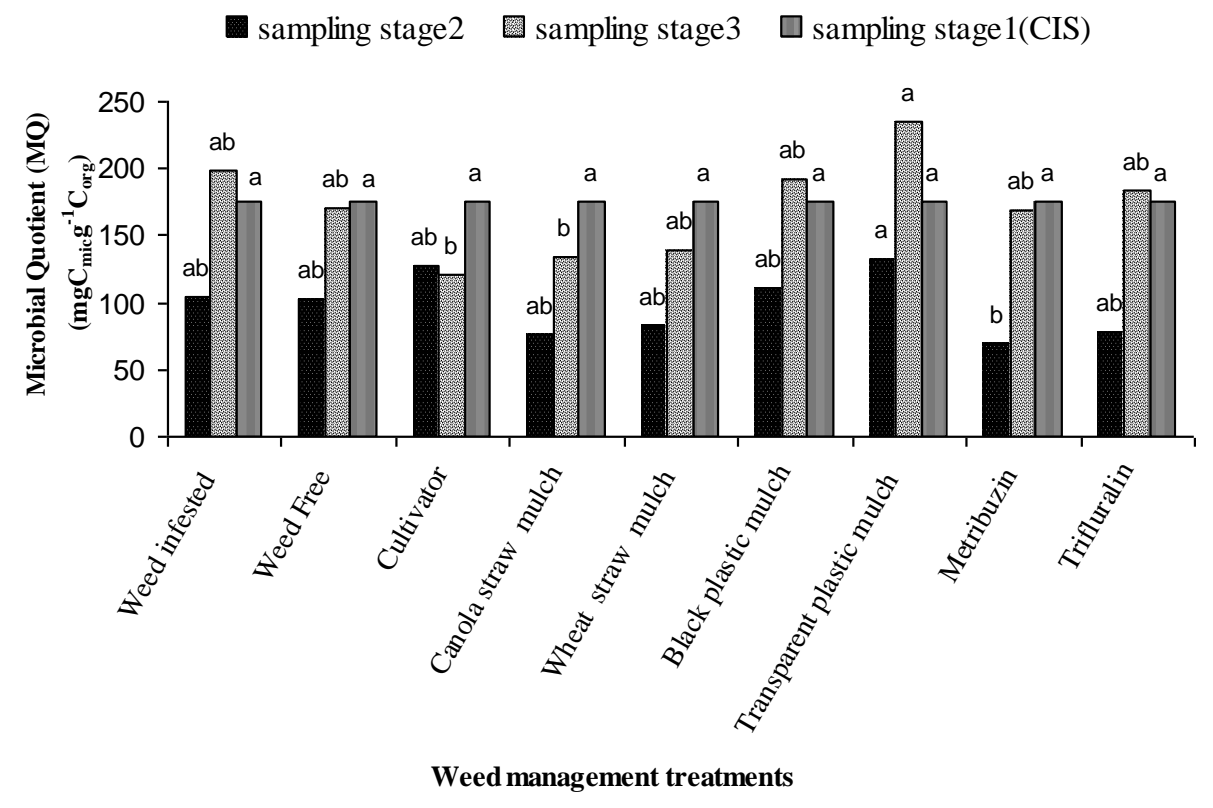

Figure 5.The effect of experimental treatments and stages (times) of sampling on microbial quotient mean of soil in potato cultivation (Means in each column followed by at least one similar letter are not significantly different at 5\% probability level, using Duncan's multiple range test.)

\section{Conclusion}

Based on the results obtained, the treatments employed could make a significant difference in the amount of microbial biomass carbon, soil organic carbon, basal respiration, microbial induced respiration, and microbial quotient. The maximum rate of microbial biomass was observed in the wheat straw mulch and canola straw mulch treatments. Soil organic carbon obtained the highest rate in wheat and canola mulch treatments compared with other treatments in the present research. The highest rate of basal respiration in the second sampling stage was related to canola mulch, wheat mulch, and black plastic mulch treatments. However, it must be noted that in this study, induced respiration indicated the highest rates in the wheat and canola mulch treatments and the lowest rates in the cultivation practices in the second sampling stage. However, 
in the third sampling stage, the rate of microbial quotient varied. In all types of treatments applied with respect to weed management, plant residues typically increased the values of all biological parameters of soil, causing a significant and positive effect on the management of organic materials. In many cases, these changes can be crucial in all types of agriculture or weed management methods. Moreover, all aspects of soil application should be taken into account in order to avoid any irreparable damages to the environment.

\section{REFERENCES}

[1] Alef, K., Nannipieri, P. (1995): Methods in applied soil microbiology and biochemistry. Academic Press. pp576.

[2] Anderson, T. H., Domsch, K. H. (1990): Application of eco-physiological quotients (qCO2 and qD) on microbial biomass from soils of different cropping histories. - Soil Biology and Biochemestry 22: 251-255.

[3] Balota, E. L., Kanashiro, M., Filho, A. C., Andrade, D. S., Dick, R. P. (2004): Soil enzyme activities under long term tillage and crop rotation systems in subtropical agroecosystems. - Brazilian Journal of Microbiology 35: 300-306.

[4] Boerner, R. E. J., Decker, K. L. M., Sutherland, E. K. (2000): Prescribed burning effects on soil enzyme activity in a southern Ohio hardwood forest: a landscape-scale analysis. Soil Biology and Biochemestry 32: 899-908.

[5] Certini, G. (2005): Effects of fire on properties of forest soils: a review. - Oecol 143: 110.

[6] Fontaine, S., Barot, S., Barre, P., Bdioui, N., Mary, B., Rumpel, C. (2007): Stability of organic carbon in deep soil layers controlled by fresh carbon supply. - Natural 450: 277280.

[7] Helgason, B., Walley, F., Germida, J. (2010): No-till soil management increases microbial biomass and alters community profiles in soil aggregates. - Appl Soil Ecology 46: 390-397.

[8] Hu, J., Lin, X., Wang, J., Dai, J., Chen, R. (2011): Microbial functional diversity, metabolic quotient, and invertase activity of a sandy loam soil as affected by long-term application of organic amendment and mineral fertilizer. - J Soil Sediment 11: 271-280.

[9] Kiikkila, O., Kanerva, S., Kitunen, V., Smolander, A. (2014): Soil microbial activity in relation to dissolved organic matter properties under different tree species. - Plant Soil 377: 169-177.

[10] Kumar, S., Sood, S., Sharma, R. C., Kasana, V. L., Pathania, B., Singh, R. D. (2014): Effect of plant spacing and organic mulch on growth, yield and quality of natural sweetener plant Stevia and soil fertility in western Himalayas. - International Journal of Plant Production 8(3): 311-334.

[11] Leite, L. F. C., Oliveira, F. C., Araújo, A. S. F., Galvão, S. R. S., Lemos, J. O. (2010): Soil organic carbon and biological indicators in an Acrisol under tillage systems and organic management in north-eastern Brazil. - Soil Reserch 48: 258-265.

[12] Li, S. X., Wang, Z. H., Li, S. Q., Gao, Y. J., Tian, X. H. (2013): Effect of plastic sheet mulch, wheat straw mulch, and maize growth on water loss by evaporation in dryland areas of China. - Agr Water Management 116: 39-49.

[13] Lu, R. K. (2000): Method of Soil Chemistry Analyses. - Agricultural Science and Technology Press of China, Beijing, pp.106-109 (in Chines).

[14] Luo, S. S., Zhu, L., Liu, J. L., Bu, D., Yue, S. C., Shen, Y. F. (2015): Sensitivity of soil organic carbon stocks and fractions to soil surface mulching in semiarid farmland. - Eur J Soil Biology 67: 35-42. 
[15] Qiu, M., Zhang, R., Xue, C., Zhang, S., Li, S. (2012): Application of bio-organic fertilizer can control Fusarium wilt of cucumber plants by regulating microbial community of rhizosphere soil. - Biolo Fert Soil 48: 807-816

[16] Roldan, A., Salinas, G. J. R., Alguacil, M. M., Diaz, E., Caravaca, F. (2005): Changes in soil enzyme activity, fertility, aggregation and $\mathrm{C}$ sequestration mediated by conservation tillage practices and water regime in a maize field. - Soil Ecology 30: 11-20.

[17] Shahrad, Z. (2010): The effect of Trifluralin herbicide on soil bacteria populations in cotton field. Master's Thesis. - Department of Soil Science, Soil and Water Engineering Group. Gorgan University of Agricultural Sciences and Natural Resources. Iran.

[18] Shirzadeh, N., Ali-Asgharzad, N., Najafi, N. (2013): Changes in Microbial Biomass Carbon, Ecophysiological indices, Basal Induced Respiration of Soil After Incubation with -Respiration and Substrate Levels Different Lead. - Water and Soil Science 23(2):111-124.

[19] Song, X., Guo, Q., Zhu, H., LI, W. (2013): Effects of two herbicides prowl and Trifluralin on microbial communities of potato soil. - Academy of Agriculture and Forestry, Qinghai University/ The Tibet Plateau Biotechnology Key Lab of Ministry of Education, Xining 810016, China.

[20] Spehn, E. M., Joshi, J., Schmid, B., Alphei, J., Korner, C. (2000): Plant diversity effects on soil heterotrophic activity in experimental grassland ecosystems. - Plant Soil 224: 217-230.

[21] Tejada, M., Garcia-Martinez, A. M., Parrado, J. (2009): Effects of a Vermi-compost composted with beet Vinasse on soil properties, soil losses and soil restoration. - Catena 77: 238-247.

[22] Torabi, S., Gherekhloo, J., Kamkar, B., Yousefi, M. (2013): Investigating the impact of the manure and trifluralin application rate on herbicide persistence in soil. - Journal of Agroecology 27( 3 ): 73-81.

[23] Vandana, L. J., Rao, P. C., Padmaja, G. (2012): Effect of herbicides and nutrient management on soil enzyme activity. - J. Rice Reserch 5: 1-2.

[24] Wei, T., Wang, L., Li, Y., Zhuang, K. M., Li, G., Zhang, J. B. (2015): Responses of microbial activity, abundance, and community in wheat soil after three years of heavy fertilization with manure-based compost and inorganic nitrogen. - Agr Ecosyst Environment 213: 219-227.

[25] Wu, J., Joergensen, R. G., Pommerening, B. (1990): Measurement of soil microbial biomass $\mathrm{C}$ by fumigation extraction — an automatic procedure. - Soil Biol. Biochemestry 22: $1167-1169$.

[26] Xia, X., Zhao, M., Wang, H., Ma, H., (2012): Influence of butachlor on soil enzymes and microbial growth. - J. Food Agri. Environment 9(2) 753-756.

[27] Yao, H. Y, He, Z. L., Wilson, M. J., Campbell, C. D. (2000): Microbial community structure in a sequence of soil with increasing fertility and changing land use on Chinese red soils. - Microbiology Ecology 40: 223-237.

[28] Zaki, M. M., Saleh, E. A., Mohamed Sonya, H., Rahal, A., Sadik, A. S., (2014): Persistence of Sencor herbicide in Streptomycetes-inoculated soil and its effect on some microbial soil. Int.J.Curr. Microbiology. - App. Science 3(3): 726-738.

[29] Zhang, F., Li, M., Qi, J., Li, F., Sun, G. (2015): Plastic Film Mulching Increases Soil Respiration in Ridge-furrow Maize Management. - Arid Land Research and Management. 29:(4) 432-453.

[30] Zhang, Q. C., Shamsi, I. H., Xu, D. T, Wang, G. H., Lin, X. Y. (2012): Chemical fertilizer and organic manure inputs in soil exhibit a vice versa pattern of microbial community structure. - Appl Soil Ecology 57: 1-8. 